\title{
Guidelines for Solid Waste Management Approaches at Kerng Sub-District Administrative Under the Maha Sarakham Provincial Administrative Organization
}

\author{
Orawan Charoenrut ${ }^{1}$ \\ ${ }^{1}$ Department of Social Science Education, Faculty of Education, Rajabhat Maha Sarakham University, Maha \\ Sarakham, Thailand \\ Correspondence: Orawan Charoenrut, Department of Social Science Education, Faculty of Education, Rajabhat \\ Maha Sarakham University, Maha Sarakham 44000, Thailand. Tel: 669-1019-9696.
}

Received: October 15, 2018

Accepted: October 30, 2018

Online Published: November 28, 2018

doi:10.20849/ajsss.v3i4.488

URL: https://doi.org/10.20849/ajsss.v3i4.488

\begin{abstract}
To integrate the problems and needs of solid waste management (SWM) for administering the SWM approach at Kerng Sub-District Administrative Organization (K-SAO) under the Maha Sarakham PAO in Thailand were studied. This SAO increasingly shares in these problem natural limited products and highly vulnerable in 14 villages are arranged with a sample size of 357 people to their perceptions with the Questionnaire on Waste Management (QWM) and the Focus Group Discussion technique in three scales; Waste Collection, Waste Separation, and Waste Disposal scales, the classifications' problems indicated that of moderate level. according to have their problems and needs, plastics bins are the type of their garbage bins, people collected the collecting SWM by the K-SAO, the households' memberships have participated in the implementation of the project with social local communities, and took part in solving problems caused by the collection of the SWM on their communities, the K-SAO has been listening to comments of their suggestions and communities' solving and given advices the burdensome problem of collecting waste to lack of responsibility. Most of guidelines the Waste Collection as to set at least twice a day and the public should be aware of the collection time and carry out their own fermentation. An importance campaign for people to sort out their sales from solid waste as Waste Separation scale was promoted. The Disposal Project Biomass Waste Treatment (MBT) was planned and organized to give pieces of advice for using disposal waste to relate waste collection time of the K-SAO was the guidelines.
\end{abstract}

Keywords: guidelines, solid waste, management approach, sub-district, provincial, administrative organization

Subject Classification: Administrative Organization of Government in Thailand onto the Sub Administrative Organization on Local Social Administration Classification.

Type (Method/Approach): To investigate to integrate the problems and needs of solid waste management (SWM) for administering the SWM approach at Kerng Sub-District Administrative Organization (K-SAO) under the Maha Sarakham PAO in Thailand were studied with the qualitative and quantitative research methods are analyzed with Survey/Interview/Focus Discussion Group/Social Communities' Perceptions.

\section{Introduction}

Thailand is a unitary state in Southeast Asia. The administrative services of the executive branch of the government are regulated by the National Government Organization Act, BE 2534 (1991). Under this Act, the services are divided into three levels: central, provincial and local. The central government consists of ministries, bureaus, and departments. Each of the ministries and bureaus is led by a minister who is a member of the Council of Ministers. A bureau may be an independent agency with the same status as a ministry or may be subject to a ministry, currently, there are no bureaus.

The ministries and bureaus are divided into departments, inter alia. Each department is led by a director general. There is a central government agency called Office of the Prime Minister. It is led by the prime minister and bears ministerial status (Organization of the government of Thailand, 2018). The provincial government consists of provinces. As of 2017 there were 76 provinces. Each province is led by a governor and is divided into districts. As of 2010, there were 878 districts throughout the country. In each province, there is one capital district. For 
example, the capital district of Chiang Mai Province is Mueang Chiang Mai District. The exception is Phra Nakhon Si Ayutthaya Province, where both the province and the capital district share the same name. Each district is led by a district chief. Until 2007, some provinces might include minor districts. A minor district was established in large areas where the small number of residents did not warrant the formation of a district. Each minor district was led by a district clerk. Governors, district chiefs, and district clerks are appointed by the central government. Under the Municipalities Act, BE 2496 (1953), the Sub-District Councils and Sub-District Administrative Organizations Act, BE 2537 (1995), and the Provincial Administrative Organizations Act, BE 2540 (1997) - The local government under this form is adopted in every province and consists of: 2,440 municipalities, which are divided into 30 city municipalities, 178 town municipalities and 2,232 Sub-District municipalities; administrative organizations which are divided into 76 provincial administrative organizations PAO; and 5,335 Sub-District administrative organizations - SAO, these are for the local communities, which are not connected to a municipality district (Organization of the government of Thailand, 2018).

Village chiefs are elected by local citizens. The chiefs of the villages in a Sub-District elect one of their numbers to also serve as the chief of the Sub-District. According to the Municipalities Act, B.E. 2496 (1953), meanwhile the new form of local government is adopted in any locality; the Minister of Interior may revoke the old form for that locality are developed. A city municipality is established in an area where there are at least 50,000 citizens, a town municipality, in an area where there are at least 10,000 citizens, and a sub-district municipality, in any other area. The government of each municipality is divided into two branches: the executive branch led by a mayor and the legislative branch led by a municipal council. The mayors and the municipal councillors are directly elected by the local citizens. As for an administrative organization, the government is also divided into two branches: the executive branch led by an administrative organization chief and the legislative branch led by an administrative organization council. The administrative organization chiefs and councillors are directly elected by the local citizens. The Sub-District Administration Organization is a local administrative organization under the Councils and Sub-district Administration Organization Act B.E. 2537, functioning as a local administrative organization at the sub-district level; it is, thus, very close to the people of the community. A Sub-district Administration Organization has developed from a Sub-District Council with income up to a certain level. It is established to manage public services at the local level, villages and sub-districts, as it is impractical for the government to administer all of the villages in the country, the number of which is over 70,000 villages (Organization of the government of Thailand, 2018).

Maha Sarakham Province is one of the 76 provinces of Thailand. It is in the North Eastern (Isan) region of Thailand. In the Maha Sarakham Provincial Administrative Organization is responsible for the development of the Maha Sarakham Province. The economy, society, education, public health, occupation, utilities such as; the construction of utilities at municipal and non-governmental organizations can't be done because of lack of budget, the construction of wastewater treatment ponds, to develop projects related to municipalities and SAO such as construction of main roads, to disaster prevention and mitigation, such as; water truck arrangement and protecting drought areas, to use of land for the benefit of the local, such as providing a place to rest the park, and to maintenance of natural resources and environment Including local customs and culture are provided. The Maha Sarakham Administrative Organization is divided to a provincial administrative organization, and 123 Sub-District administrative organizations, Kerng is the one of the-123 Sub-District administrative organizations of Thailand under Maha Sarakham Provincial Administrative Organization (Department of Provincial Organization, 2014).

In the context of Kerng Sub-District, this area is a plain of Chi river that flows through, making the area fertile, suitable for agriculture both in and out of season. It consists of 14 Villages, 9,236 populations from 4,463 households, and has a total area of 11,983 Rai of agricultural land, 9,037.25 Rai, accounting for $75.42 \%$ of the total area. The agricultural area of the district is divided into 7,252 Rai or 80.25 percent of the agricultural area. The area of the fruit is 1,566 Rais, accounting for 17.33 percent of the area. Other areas such as flower growing area are 19.25 Rais 0.21 of the area of agriculture. This sub-district administration organization entails two branches: the legislative branch and the executive branch. The legislative branch entails members of the organization; their main duties are to pass the local laws and monitor the administrative affairs of the sub-district. The executive branch is led by the president of the organization who chairs the sub-district administration organization. The chair of a Sub-District Administration Organization (SAO) is elected by the people functioning as the head of the administrative branch, and the term is four years. Members of the sub-district administrative organization are directly elected by the people of the community; their administrative term lasts for four years. The number of the members of for each sub-district varies, depending on the number of villages within a particular sub-district. The sub-district organization of only one village can only have five members. If 
the number of villages is two representations, each village is allowed to vote for three representatives. The organization with more than two villages is allowed to have two representatives for each village (Department of Local Organization, 2018). Disposal of solid waste is a worldwide problem. The SAO of Thailand increasingly shares in these problem natural products. Waste could be discarded to decompose naturally. Today, according to one observer, "...it would not be an exaggeration to say that every locality in the country is...mired in its own garbage." Thailand's Pollution Control Department estimates that each Thai produces a daily average of $1.15 \mathrm{~kg}$ of solid waste, amounting to over 73,000 tons daily nationwide. According to Interior Ministry statistics, refuse nationwide in 2016 amounted to 27 million tons, up about 0.7 per cent from the previous year. Of this, 4.2 million tons was generated in Bangkok.[99] Thailand had 2,490 dump sites in 2014, but only 466 of them were of sanitary landfill calibre. Twenty-eight million tons of waste was left unprocessed. Bangkok's canals are awash in sewage, but also serve as dump sites. After recent severe flooding, tons of refuse blocked water gates, preventing drainage. At one water gate, more than five tons of debris had accumulated, consisting of everything from everyday consumer product waste to large items such as mattresses and furniture. However, to be fair, the waste management roadmap does contain a proposal to "instil discipline to achieve sustainable management", including enforcing laws against illegal dumping and launching campaigns to Raise (Techawongtham, 2016).

To overcome these problems, the waste management area is expanding and this document is the first of what is hoped to be a series to address solid and chemicals waste management issues in Kerng-Sub-District Administration Organization. The majority of solid waste produced in the region is due to rapid urban isolation; this is compounded by an equally rapid rise in 'standard of living' expectations which relate to an increased demand for imported canned, plastic-wrapped and bottled goods. With limited location areas around many village centres and with local reefs, surrounding the land with the Chi River, particularly vulnerable to pollutions have serious disposal problems. Only a very small number of disposal sites are acceptable socially, economically, or from the viewpoint of health. These problems are exacerbated in atoll Kerng-SAO with very limited land areas and highly vulnerable with solid wasted from people in these 14-villages are arranged.

Waste (or wastes) is unwanted or unusable materials. Waste is any substance which is discarded after primary use, or is worthless, defective and of no use, which include municipal solid waste (household trash/refuse), hazardous waste, wastewater (such as sewage, which contains bodily wastes (faces and urine) and surface runoff), radioactive waste, and others. "'Wastes' are substance or objects, which are disposed of or are intended to be disposed of or are required to be disposed of by the provisions of national law". There are many waste types defined by modern systems of waste management, notably including Municipal waste includes household waste, commercial waste, and demolition waste, hazardous waste includes industrial waste, biomedical waste includes clinical waste, or special hazardous waste includes radioactive waste, explosive waste, and electronic waste (e-waste) (First Post News, 2016).

There are many issues that surround reporting waste. It is most commonly measured by size or weight, and there is a stark difference between the two. For example, organic waste is much heavier when it is wet and plastic or glass bottles can have different weights but be the same size. On a global scale, it is difficult to report waste because countries have different definitions of waste and what falls into waste categories, as well as different ways of reporting. Based on incomplete reports from its parties, the Basel Convention estimated 338 million tons of waste was generated in 2001. For the same year, OECD estimated 4 billion tons from its member countries. Despite these inconsistencies, waste reporting is still useful on a small and large scale to determine key causes and locations and to find ways of preventing, minimizing, recovering, treating, and disposing of waste (Yukako \& Iwamoto, 2016).

Waste is not only an environmental problem but also an economic loss. For example: the UNSD Glossary of Environment Statistics (2013) describes waste as "materials that are not prime products (that is, products produced for the market) for which the generator has no further use in terms of his/her own purposes of production, transformation or consumption, and of which he/she wants to dispose. Wastes may be generated during the extraction of raw materials, the processing of raw materials into intermediate and final products, the consumption of final products, and other human activities. Residuals recycled or reused at the place of generation are excluded." on average Europeans produce 481 kilograms of municipal waste per year. An increasing share of this is recycled or composted, and less is sent to landfill. How can we change the way we produce and consume so as to produce less and less waste while using all waste as a resource? The generates large amounts of waste food and garden waste, construction and demolition waste, mining waste, industrial waste, sludge, old televisions, old cars, batteries, plastic bags, paper, sanitary waste, old clothes and old furniture... the list goes on (The United Nations Environment Programme, 2005). 
The amount of waste is closely linked to the consumption and production patterns. The sheer number of products entering the market poses yet another challenge. Demographic changes, like an increase in the number of one-person households, also affect the amount of waste at this recent generate (e.g. packaging goods in smaller units) (The U.S. Environmental Protection Agency, 2009). The large spectrum of waste types and complex waste-treatment paths (including illegal ones) makes it difficult to get a complete overview of the waste generated and its whereabouts. There are data, albeit of varying quality, for all types of waste. According to data for 2010 for 29 European countries (i.e. EU-28 and Norway), around $60 \%$ of the waste generated consisted of mineral waste and soil, largely from construction and demolition activities and mining. For metal, paper and cardboard, wood, chemical and medical waste and animal and vegetal wastes, each waste type ranged from $2 \%$ to $4 \%$ of the total. Around $10 \%$ of the total waste generated that it consists of what is known as 'municipal waste' - waste generated mainly by households, and to a lesser extent by small businesses, and by public buildings such as schools and hospitals. In 2012, $481 \mathrm{~kg}$ of municipal solid waste was generated per person in the 33 member countries of the European Environment Agency (EEA). There is a slight downward trend from 2007 onwards, which can be explained partly by the economic crisis affecting Europe since 2008 (European Environment Agency, 2014).

Waste management is a significant environmental justice issue. Many of the environmental burdens cited above are more often borne by marginalized groups, such as racial minorities, women, and residents of developing nations. NIMBY (not in the backyard) is the opposition of residents to a proposal for a new development because it is close to them. However, the need for expansion and sitting of waste treatment and disposal facilities is increasing worldwide. There is now a growing market in the Transboundary movement of waste, and although most waste that flows between countries goes between developed nations, a significant amount of waste is moved from developed to developing nations (Wolsink, 1994).

Education and awareness in the area of waste and waste management are increasingly important from a global perspective of resource management. The Tallies Declaration is a declaration for sustainability concerned about the unprecedented scale and speed of environmental pollution and degradation, and the depletion of natural resources. Local, regional, and global air pollution; accumulation and distribution of toxic wastes; destruction and depletion of forests, soil, and water; depletion of the ozone layer and emission of "greenhouse" gases threaten the survival of humans and thousands of other living species, the integrity of the earth and its biodiversity, the security of nations, and the heritage of future generations. Several universities have implemented the Talloires Declaration by establishing environmental management and waste management programs, e.g. the waste management university project. University and vocational education are promoted by various organizations, e.g. WAMITAB and Chartered Institution of Wastes Management (Wilson, Velis, \& Cheeseman, 2006).

Experts on waste management and environmental protection are warning that Thailand could become the garbage bin of the world, as the government's policies to promote the waste-to-energy industry have already resulted in plastic waste imports to the Kingdom. Ecological Alert and Recovery Thailand, the country's recent waste management trends run counter to correct waste management methods. The government's current path will prevent a proper solution to waste management problems and unintentionally lead to waste from other countries being dumped in Thailand, singles out for criticism the promotion of private investment in small waste-to-energy projects across the country (Rujivanarom, 2018).

Waste-to-energy is one of the most polluting methods for both waste management and power generation, because not only will burning garbage emit toxic pollutants, but the leftover ashes are also very hazardous and require very careful disposal in a secured landfill. And so building many small waste-to-energy plants is a very bad decision. To contest the advantages of waste-to-energy, as it is one of the acceptable measures to deal with unrecyclable waste, but the organization should have only a few big waste-to-energy plants that are properly equipped with all pollution control measures. Highlighting to concern over the small size of the waste-to-energy projects now being promoted by the government, it was not cost-effective for the investors to install expensive pollution-control systems. They are forced to reduce the money spent on environmental protection in order to keep their investment profitable (Rujivanarom, 2018).

In Thailand, the responsibility for waste management has been decentralized to the local administrative organizations. However, presently, it is still observed that most of the local administrative organizations fail to fulfil this duty due to the insufficiency of the budget, and the limited area for managing waste. In a district, currently and increasingly faced with the waste problem as a consequence of both the expansion of the growth of the community itself has been invented. In spite of this, $60 \%$ of the local administrative organizations within each District possessed no process to manage the waste. Thus, the huge amount of accumulated waste has been 
left without proper handling. The limitation of these local administrative organizations was due to their areas and landscape situated in the wide and urban areas according to the Thai law, this specific area was classified as a conservative implies waste management could not be done without official permission. However, the households within each area were aware of the problem and collaborated with the local administrative organizations in applying 5R Principle to decrease the amount of waste from its source (Gheewala, 2011).

According to the five-year waste management master plan, local administrative organizations are required to manage waste. However, the private sector is also encouraged to invest in waste disposal plants, based on the assumption that they are abler and ready to properly oversee waste disposal. Forty-four provinces meet the criteria, allowing them to initiate private-sector investment in waste-to-energy plants. Those criteria include the availability of a feed-in power line, the ability to ensure a feedstock of at least 300 tons of garbage (Ray, 2008). In contrast, a total of 102 areas in 49 provinces have the capacities for investment in refuse-derived fuel processing plants. For the less populated areas that have below 50 tons of waste generated per day, the authorities and residents are advised to locally process their waste into fertilizer and bury the leftover garbage in a local sanitary landfill.

In this research study, focused on guidelines for solid waste management approaches at Kerng Sub-District Administrative Organization under the Maha Sarakham Provincial Administrative Organization have been prepared by this research report to assist the 14 local villages at Kerng-SAO to develop and implement their own solid waste management plans. The Guidelines bring together a number of aspects of solid waste management common to all of the 14-villages, and provide a process to follow and resource material that individual villages can use to develop their own Action Plans for Solid Waste Management. The collected solid waste was disposed of in the landfill of the municipality of Maha Sarakham in the public forest area, which is the public land. This problem has never studied the basics of solid waste management in the community. Thus, the implementation of the solid waste management plan has no clear and effective. This section should be succinct, with no subheadings.

\section{Materials and Methods}

Using the Qualitative and Quantitative method to design on local government administration to manage the waste problem on solid waste management is directly responsible for the municipal and Sub-District administrative organizations and the Sub-District Administration Organization, Raised from the Sub-District Council, formerly known as Kerng Sub-District Administrative Organization under the Maha Sarakham PAO of 14 Villages. The garbage collection from Monday to Friday was attended by one local health and environmental officer, three garbage trucks and three garbage collectors. Zone 2 is the first zone of 7 villages to be collected every Monday and Thursday. Zone 2 of 7 villages are held every Tuesday, Wednesday and Friday by the Kerng $\mathrm{SAO}$ has provided garbage containers to the public, which composts of 2 sizes of plastic trash, green, size 100 Liter and trash bin made of 20 size rubber tires, which can collect 1-2 rubles a day is managed, the research procedures are planned to the subsections that follow as:

\subsection{Research Aims}

1. To integrate the problems and needs of solid waste management in the Kerng Sub-District Administrative Organization under the Maha Sarakham PAO

2. To administer the waste management approach of Kerng Sub-District Administrative Organization under the Maha Sarakham PAO to be effective.

\subsection{Research Limitations}

This research study focused on the guidelines for solid waste management approaches at Kerng Sub-District Administrative Organization under the Maha Sarakham PAO was planned.

The scope of the Content: To investigate of the problems and needs of solid waste management in the community and the waste management approach in four steps: the collection of garbage, change the garbage, reuse, and final disposal of the Kerng SAO.

Scope of Area: The responsibility area is the community waste management located in Kerng SAO whereas it composts of 14 villages, namely: Dindam, Nontum, Wang Youw, Southern Kerng, Northern Kerng, Khong Kood Wai, Tung Na Row, Nonsomboon, Nonsawan, Dindam Pattana, Charoensuk, Kerng Pattana, and Wang Nam Yean Villages are administered. 


\subsection{Population Limitations}

To be selected throughout 14 villages in the Kerng Sub-District Administrative Organization under the Maha Sarakham PAO. The population is divided into 2 groups:

Group 1: Household representatives, which the population consisted of 2,092 persons from 14 villages, were selected.

Group 2: Community leaders and representatives of Kerng SAO under the Maha Sarakham PAO, which composed of the 3-management administration of the SAO; one of the head administrator, the vice president of the SAO, and one of which is responsible for public health and the environment, and one secretary of the SAO. The Chairman of the Council Provincial Administrative Organization consists of 22 members, the member representation votes of 28 villages in each village, and sub-district employees and 3 garbage collectors.

\subsection{Sample Size}

The sample size was determined according to Yamanashi method (Yamane, 1967: 886) with purposive random sampling was selected and consisted of 1 Sub-District Headman, 14 Village Headmen, 20 representative personnel of the Kerng SAO, 28 Members of the Village of Representative, and 3 Garbage Service Personnel. The totalized sample consisted of 357 respondents.

\subsection{Research Instruments}

\subsubsection{The Quantitative Instrument}

The Questionnaire on Waste Management (QWM) was assessed the sample group of their perceptions to their problems and needs of the community toward their solid waste management by creating an open-ended questionnaire in four sections, such as;

Section 1: General status of the respondents' data was gender, age, education, the main occupation of the family, number of family membership, and household income.

Section 2: Household waste was classified as waste data; Waste quantity, and the source of the waste.

Section 3: Household waste management information data that includes; people, money, equipment and tools, and Management of Various Areas that includes Collection, Change, Processing \& Recycling, and Final disposal.

Section 4: Problems and needs in solid waste management in the community data include; garbage collection, garbage collection change of state reuse, and final disposal. The questionnaire was open-ended.

\subsubsection{The Qualitative Instrument}

Managing data design with the issues in group discussion to brainstorm with Focus Group Discussion on two steps:

First Step: The household representatives from 14 villages who responded of their perceptions on the QWM Questionnaire to investigate their problems and needs to their community solid waste management were assessed.

Second Step: Organize meetings to brainstorm with focus group discussion; participants in the group discussion and participation are community leaders, and representatives of the Kerng SAO were participated to restore the information obtained from the first step.

\subsection{Data Analysis}

Qualitative data was analyzed with classification, interpretation data, and content analysis and descriptive analysis was reported. The focus group discussion was responded with the content analysis and descriptive analysis was analyzed.

Quantitative data was assessed the sample's perceptions of their QWM questionnaire, and their responses with percentage, mean, standard deviation were analyzed.

\section{Results and Discussion}

Research on guidelines for solid waste management approaches at Kerng Sub-District administrative organization under the Maha Sarakham PAO was a mixed combination of quantitative and qualitative research for educating the achievement of the objectives of this research study. 
3.1 To Integrate the Problems and Needs of Solid Waste Management in the Kerng SAO Sub-District Under the Maha Sarakham PAO

\subsubsection{General Sample Data}

To investigate of the general status of respondents' data in this research was collected data from residents living in the baseline survey of the communities. Using the QWM that tantalization of 360 copies was received, 357 were returned, representing 99.16 per cent of the total. The general status of the respondents' sample responded as shown in Table 1.

Table 1 . The general status of respondents' data, accounting data, and percentage (\%)

\begin{tabular}{|c|c|c|}
\hline General Status Of Respondents' Data & Accounting Data & Percentage $(\%)$ \\
\hline \multicolumn{3}{|l|}{ Sex } \\
\hline Male & 195 & 54.62 \\
\hline Female & 162 & 45.38 \\
\hline \multicolumn{3}{|l|}{ Age } \\
\hline Less than 25 years old & 37 & 10.36 \\
\hline From 26 to 30 years old & 77 & 21.57 \\
\hline From 31 to 35 years old & 96 & 26.89 \\
\hline From 36 to 40 years old & 49 & 13.72 \\
\hline From 46 to 50 years old & 41 & 11.48 \\
\hline More than 51 years old & 57 & 15.97 \\
\hline \multicolumn{3}{|l|}{ Educating Classification } \\
\hline Non educated performance & 5 & 0.13 \\
\hline Primary Education & 183 & 51.26 \\
\hline Secondary Education & 117 & 32.77 \\
\hline Undergrad Education & 31 & 8.68 \\
\hline Bachelor Education & 21 & 5.88 \\
\hline \multicolumn{3}{|l|}{ Occupation } \\
\hline Merchant/Self-business & 33 & 9.24 \\
\hline Government service/state enterprise & 14 & 3.92 \\
\hline Agriculture & 224 & 62.74 \\
\hline General service & 82 & 22.97 \\
\hline Private company employees) & 4 & 0.11 \\
\hline \multicolumn{3}{|l|}{ Households' Environment } \\
\hline Community whereas far from the Garbage & 229 & 64.14 \\
\hline $\begin{array}{l}\text { Sources } \\
\text { Community whereas it is surrounding at the } \\
\text { Garbage Sources }\end{array}$ & 128 & 35.86 \\
\hline
\end{tabular}

Note : $\mathrm{N}=357$

In Table 1 reported the general background of the sample size consisted of 357 people who responded of their status, most of the sample was male, their age was ranged from 30 to 35 years old, primary education of their educational classification, agriculture as their occupation, and the location of their household has stayed far from the garbage sources.

\subsubsection{Sample's Responses of Their Perceptions to Their Solid Waste Management Approaches}

The sample group responded of their participating solid waste management approaches, the results have found that of the waste management approaches of Kerng SAO under the Maha Sarakham PAO, it was reported in Table 2. 
Table 2. Percentage of sample's responses of their perceptions to their solid waste management approaches for the QWM

\begin{tabular}{lll}
\hline Item & Solid Waste Management Approaches & $\begin{array}{l}\text { Accountin } \\
\text { g Percen } \\
\text { tage } \\
\text { Responses }\end{array}$ \\
& &
\end{tabular}

1. The guidelines for collecting solid waste management in households

Takes it into the plastic page and takes it out 104

Deposits in front of household

Deposits in the surrounding household area

Takes it into the garbage bin in front of household

2. Does the garbage bin for collecting the solid waste management have been closed with the bin lid, completely?

Yes

No

3. Do Kerng's SAO have been participated to the solid waste management approaches?

4. How does your household have been participated of your community and Kerng's SAO according to have your problems and needs?

To have the first idea for being corrected the solid waste management of your community

To have time schedule for collecting solid waste management

To have the participating payment fee of the garbage fund

To have the participating invitation of your collecting waste management approaches

To have the participating the focus group discussion and taking your opinions projects

To attend the participating projects that involving the environmental cleaning

5. What does the type of your garbage bin of your household?

Bamboo garbage bin

Plastic bin

Oil truck reuse

Plastic bag

Car wheel rubber reuse bin

6. How does your collecting solid waste in your community of your household?

No have collected the solid waste management (To self management and destroyed it)

To be collected by the Kerng SAO collected by the SAO

7. Your household participates in the implementation of the project. Collection Is there a waste in your community?

$\begin{array}{ll}.1 \mathrm{Yes} & 331 \\ .2 \mathrm{No} & 26\end{array}$

8. Does your household take part in solving problems caused by the collection of solid waste in your community?

$.9 \quad$ SAO has been listening to comments. Your suggestions and community Solving 
the burdensome problem of collecting waste in your community?

Yes

No

10. What role does the SAO play in garbage collection in your community (more than one answer)?

Give advice.

Be an example to the public.

Motivation by reward

Applying penalties

Ask for cooperation and support.

11. How do you think the community does not cooperate with the SAO in the field of waste management? Why (more than one answer)

Lack of responsibility

The people responsible for the work of the SAO are unrelated. management.

Note: $\mathrm{N}=357$

In table 2 reported to describe of sample's responses of their perceptions to their solid waste management approaches for the QWM was managed. Most of their perceptions to their guidelines for collecting solid waste management in households as to take it into the garbage bin in front of household, the garbage bin for collecting the solid waste management have been closed with the bin lid, Kerng's SAO have participated to the solid waste management approaches, the households have their participating payment fee of the garbage fund to their participation and their community at Kerng's SAO according to have their problems and needs, plastics bins are the type of their garbage bins, people collected the collecting waste management by the Kerng SAO, the households' memberships have participated in the implementation of the project with social local communities, the households have taken part in solving problems caused by the collection of solid waste in their communities, the SAO has been listening to comments about their suggestions and communities' solving and given pieces of advice the burdensome problem of collecting waste to Lack of responsibility in the field of waste management from the SAO.

\subsubsection{The Resulting Investigations of Waste Management Problems}

Sample group responses of their perceptions to their investigations of waste management problems for the Kerng $\mathrm{SAO}$, Table 3 shows the resulting investigations of waste management problems were analyzed.

Table 3. Means, standard deviation, and classification problems in three scales for the QWM

\begin{tabular}{lllll}
\hline $\begin{array}{l}\text { Scale } \\
\text { No. }\end{array}$ & $\begin{array}{l}\text { Problems of Solid Waste } \\
\text { Management }\end{array}$ & Means (X) & $\begin{array}{l}\text { Standard } \\
\text { Deviation } \\
\text { (S.D.) }\end{array}$ & $\begin{array}{l}\text { Classification } \\
\text { Problems }\end{array}$ \\
\hline 1. & Waste collection & 2.61 & 1.21 & Moderate \\
2. & Waste separation & 2.83 & 1.28 & Moderate \\
3. & Waste disposal & 2.74 & 1.24 & Moderate \\
\hline & Total & $\mathbf{2 . 7 3}$ & $\mathbf{1 . 9 8}$ & Moderate \\
\hline
\end{tabular}

Note: $\mathrm{N}=357$

In Table 3 reported to the sample group responses of their perceptions to their investigations toward their waste management problems by the Kerng SAO in three scales, namely; Waste Collection, Waste Separation, and Waste Disposal scales. The average mean scores ranged from 2.61 to 2.63 , and standard deviation ranged from 1.21 to 1.28 for the QWM questionnaire, the classifications' problems indicated that of moderate level. 


\subsection{To Investigate the Affecting Guidelines of the Waste Management Approach of the Kerng SAO Under the Maha Sarakham PAO}

Using the qualitative method to investigate the guidelines for solid waste management approaches at Kerng Sub-District Administrative Organization under the Maha Sarakham PAO, the results of this study on the development of solid waste management, which workshop was held on July 28, 2016 at the meeting room of the Kerng's SAO is reported in Table 4-6.

Table 4. Focus group discussion on the guidelines for solid waste management approaches at Kerng SAO under the Maha Sarakham PAO for waste collection scale

\begin{tabular}{|c|c|}
\hline $\begin{array}{l}\text { Data } \\
\text { Respectively }\end{array}$ & The Guidelines for Solid Waste Management Approaches \\
\hline 1 & $\begin{array}{l}\text { The waste collection time should be set at least twice a day and the public should be aware of } \\
\text { the collection time. In order for people to remove solid waste. Relate to garbage collection time } \\
\text { that following as the municipality' schedule time }\end{array}$ \\
\hline 2 & $\begin{array}{l}\text { There should be a committee to monitor the work of the employees to collect the garbage for } \\
\text { working full capacity. }\end{array}$ \\
\hline 3 & $\begin{array}{l}\text { The waste collection route should be developed to reduce the operating costs and the } \\
\text { repeatability of the route }\end{array}$ \\
\hline 4 & $\begin{array}{l}\text { Collected training should be provided for the collection of sanitary waste for community } \\
\text { leaders. In order for community leaders to explain properly to the people in the community }\end{array}$ \\
\hline 5 & $\begin{array}{l}\text { When the people were involved in solving the problem of garbage collection. Attention of the } \\
\text { projects should also be given to the opinions and suggestions of the people. }\end{array}$ \\
\hline 6 & The garbage cans should be cleaned at least once a month \\
\hline 7 & Appropriate waste collection methods should be established \\
\hline 8 & $\begin{array}{l}\text { The budget should be allocated to employees, garbage collectors and garbage trucks adding } \\
\text { more }\end{array}$ \\
\hline 9 & Training should be provided to staff at all levels. \\
\hline 10 & $\begin{array}{l}\text { The SAO should promote the participation of people in the cleanliness of the community. } \\
\text { People in the community are responsible for the management of solid waste and cleaning in the } \\
\text { community. There is a community of non-trash and road-free trash operators who provide } \\
\text { advice on waste management. To make the community look more beautiful. }\end{array}$ \\
\hline
\end{tabular}

Table 5. Focus group discussion on the guidelines for solid waste management approaches at Kerng SAO under the Maha Sarakham PAO for waste separation scale

\begin{tabular}{|c|c|}
\hline $\begin{array}{l}\text { Data No. } \\
\text { Respectively }\end{array}$ & The Guidelines for Solid Waste Management Approaches \\
\hline 1 & $\begin{array}{l}\text { The SAO should be made aware that people in the community are aware of the importance of } \\
\text { separating solid waste and that people are aware of the problem of solid waste for continuing } \\
\text { self and society? }\end{array}$ \\
\hline 2 & $\begin{array}{l}\text { Garbage trucks should be collected separately from the collection process from the source. } \\
\text { Garbage at various points. Then dispose of into disposal site }\end{array}$ \\
\hline 3 & $\begin{array}{l}\text { Community/SAO's punishments should be provided for those who do not dump garbage in the } \\
\text { area, and SAO is strictly defined and serious. }\end{array}$ \\
\hline 4 & $\begin{array}{l}\text { The SAO is advisable to keep } 3-5 \text { garbage cans and hazardous waste at least } 3-5 \text { communities } \\
\text { and collect them. Daily toxic waste }\end{array}$ \\
\hline 5 & $\begin{array}{l}\text { The SAO should be a campaign for people in the community to sort out their sales from solid } \\
\text { waste, such as organizing a design competition for waste products. Disposal Project Biomass } \\
\text { Waste Treatment (MBT) Recycling Bank Project for managing the market of the sale. }\end{array}$ \\
\hline 6 & The SAO should be provided only in a densely populated community. \\
\hline 7 & $\begin{array}{l}\text { The SAO should publicize the training on garbage separation, reducing waste and } \\
\text { Properly managed waste management for household waste managers of those who }\end{array}$ \\
\hline
\end{tabular}


memberships in the SAO.

8

9

10

The SAO should be supported for people who work in the community to buy, sell, donate, sell, give to the poor in the community or measure closing bin lids

The SAO should be had a campaign for people to sort out biodegradable waste and carry out their own fermentation, which may be done at home. This is a group of households that are engaged in fermentation, and a bio-fertilizer club was established to disseminate knowledge about exchanges of experiences in bio-waste.

The SAO should organize a public relations campaign, redeem the sale out of solid waste household level, they also provide training on waste management in the community with a variety of operations.

Table 6. Focus group discussion on the guidelines for solid waste management approaches at Kerng SAO under the Maha Sarakham PAO for waste disposal scale

\begin{tabular}{ll}
\hline $\begin{array}{l}\text { Data } \\
\text { Respectively }\end{array}$ & The Guidelines for Solid Waste Management Approaches \\
\hline 1 & The SAO should be publicized how to dispose of the garbage that is hygienic to the public. \\
2 & The SAO's construction of a waste disposal site should be undertaken the Gibraltar to be \\
& supervised for integrating the experts are close. \\
& The SAO should expand the area of the waste bins more and not to smell foul odors public. \\
4 & The SAO's staff that is knowledgeable about the disposal of sanitary waste to complete their \\
& work capable and powerful. \\
& The SAO should be developed to improve the efficiency of waste disposal by using the disposal \\
& method. Solid waste is a mechanical-biological waste treatment (MBT) to be reduced the \\
environmental impact. As a result, the volume of waste landfill collapsed, thus reducing the area \\
to be used. \\
The SAO should be had an ongoing campaign for the disposal of solid waste such as once a \\
month to Raise public awareness of the problem for finding waste that impacts, and \\
self-environment. \\
Focusing on the SAO should be participated on people's participation in solid waste management \\
of the participation and community building continued. \\
The SAO should be provided with volunteer support and the volunteer tRaining environment to \\
participate in environmental campaign activities with the SAO; the volunteer team, the \\
environment is down, collecting environmental problems, analyzing problems, planning \\
problems, solving problems together with the SAO. \\
The SAO should select the community committee that came from the election for working with \\
the community, it is the policy of the community to plan and organize its own projects and give \\
advice to the community.
\end{tabular}

In Table 4-6 reported to investigate the affecting guidelines of the waste management approach of Kerng SAO under the Maha Sarakham PAO are description with the Focus Group Discussion technique in three scales, namely; Waste Collection, Waste Separation, and Waste Disposal scales. Most of guidelines for solid waste management approaches from the people's responses indicate that of the Waste Collection scale as to set at least twice a day and the public should be aware of the collection time, especially, the committee to monitor the work of the employees to collect the garbage for working full capacity and to develop for reducing the operating costs and the repeatability of the route to have a campaign for people to sort out biodegradable waste and carry out their own fermentation, and organizing a public relations campaign, redeeming the sale out of solid waste household level, they also provide training on waste management in the community with a variety of operations. 


\subsection{Main Text (Review only)}

In terms of the Waste Separation scale; the SAO should be made aware that people in the community are aware of the importance of separating solid waste from the garbage trucks are collected, strictly defined and serious. An importance campaign for people in the community to sort out their sales from solid waste, such as organizing a design competition for waste products, disposal Project Biomass Waste Treatment (MBT) for Recycling Bank Project for managing the market of the sale is planned. The SAO should organize a public relations campaign, redeem the sale out of solid waste household level, they also provide tRaining on waste management in the community with a variety of operations.

Focused on the Waste Disposal scale was discussed, the publication is disposed of the garbage that is hygienic to the public, the Gibraltar to be supervised for integrating control to smell foul odors public to improve the efficiency of waste disposal by using the disposal method for the disposal of solid waste such as; once a month to Raise public awareness of the problem for finding waste that impacts, and self-environment. Solid waste is a mechanical-biological waste treatment (MBT) to be reduced the environmental impact of the participation and community building continued with volunteer support and the volunteer tRaining environment to participate in environmental campaign activities with the SAO are provided. The policy of the community to plan and organize its own projects and give advice to the community are made the selection to use disposal waste to relate to waste collection time of the SAO, respectively.

\section{Conclusions}

Qualitative and quantitative research methods on the guidelines for solid waste management approaches to be effective were sellected. Kerng Administrative Organization has been prepared to assist the 14 local villages. The Guidelines bring together a number of aspects of solid waste management common to all of the 14-villages; and provide a process to follow and resource material that individual villages can use to develop their own Action Plans. Under this Act, the services are divided into three levels: central, provincial and local. The central government consists of ministries, bureaus, and departments. Each department is led by a director general. The local government under this form is adopted in every province and consists of: 2,440 municipalities, which are divided into 30 city municipalities, 178 town municipalities and 2,232 Sub-District municipalities; administrative organizations which are divided into 76 provincial administrative organizations - PAO; and 5,335 Sub-District administrative organizations - SAO, these are for the local communities, which are not connected to a municipality district. Maha Sarakham Province is one of the 76 provinces in Northeastern Region of Thailand. The Maha Sarakham Administrative Organization is divided into 1 provincial administrative organization, and 123 Sub-District administrative organizations, Kerng SAO is one of the-123 Sub-District administrative organizations of Thailand under Maha Sarakham Provincial Administrative Organization.

To integrate the problems and needs of solid waste management and to administer the waste management approach of the Kerng Sub-District Administrative Organization under the Maha Sarakham PAO in Thailand were designed. The SAO of Thailand increasingly shares in these problem natural products. Waste could be discarded to decompose naturally. These problems are exacerbated in atoll Kerng-SAO with very limited land areas and highly vulnerable with solid wasted from people in these 14-villages are arranged. However, waste management is a significant environmental justice issue. The limitation of these local administrative organizations was due to their areas and landscape situated in the wide and urban areas according to the Thai law, this specific area was classified as a conservative implies waste management could not be done without official permission.

The population of Kerng Sub-District Administrative Organization consisted of 2,092 persons from 14 villages; the sample size determined according to Yamanashi method (Yamane, 1967: 886) with purposive random sampling was selected and consisted of 1 Sub-District Headman, 14 Village Headmen, 20 representative personnel of the Kerng SAO, 28 Members of the Village of Representative, and 3 Garbage Service Personnel. The totalized sample consisted of 357 respondents. Using the Questionnaire on Waste Management (QWM) was assessed the sample group of their perceptions to their problems and needs of the community toward their solid waste management by creating an open-ended questionnaire in four sections, and administer data design with the issues in group discussion to brainstorm with Focus Group Discussion on two steps. Qualitative data was analyzed with classification, interpretation data, and content analysis and descriptive analysis was reported. The focus group discussion was responded with the content analysis and descriptive analysis was analyzed. Quantitative data was assessed the sample's perceptions of their QWM questionnaire, and their responses with percentage, mean, standard deviation were analyzed. 
The results have found that; the general background of the sample size consisted of 357 people who responded of their status, most of the sample was male, their age was ranged from 30 to 35 years old, primary education of their educational classification, agriculture as their occupation, and the location of their household has stayed far from the garbage sources. Most of their perceptions to take it into the garbage bin in front of household, the garbage bins have been closed with the bin lid, the households have been participating payment fee of the garbage fund to their participation of their community at Kerng's SAO according to have their problems and needs, plastics bins are the type of their garbage bins, people collected the collecting waste management by the Kerng SAO, the households' memberships have participated in the implementation of the project with social local communities, the households' memberships have participated in the implementation of the project with social local communities, the households have taken part in solving problems caused by the collection of solid waste in their communities, the SAO has been listening to comments of their suggestions and communities' solving and given prices of advice the burdensome problem of collecting waste to Lack of responsibility in the field of waste management from the SAO.

The waste management problems were assessed in three scales, namely; Waste Collection, Waste Separation, and Waste Disposal scales. The average mean scores ranged from 2.61 to 2.63, and standard deviation ranged from 1.21 to 1.28 for the QWM questionnaire, the classifications' problems indicated that of moderate level. Focus Group Discussion technique in three scales, namely; Waste Collection, Waste Separation, and Waste Disposal scales. Most of the guidelines for solid waste management approaches from the people's responses indicate that of the Waste Collection scale as to set at least twice a day and the public should be aware of the collection time and to develop for reducing the operating costs and the repeatability of the route to have a campaign for people to sort out biodegradable waste and carry out their own fermentation. An importance campaign for people in the community to sort out their sales from solid waste, such as organizing a design competition for waste products, disposal Project Biomass Waste Treatment (MBT) for Recycling Bank Project for managing the market of the sale is planned. The policy of the community to plan and organize its own projects and give advice to the community are made the selection to use disposal waste to relate to waste collection time of the SAO, respectively.

\subsection{Data Availability (Excluding Review Articles)}

Local governments have the possibility to borrow to implement three main types of projects: Purchase of land and/or construction of governmental buildings, projects to improve and/or develop infrastructure, and purchase of durable goods. Until 1997, local governments were restrained to borrow from the Local Development Fund, which is controlled by the Ministry of Interior who gives approbation for the amount of deficit a local government can carry. With the local governments being authorized to contract debt from the financial institution with approval granted by the provincial governor, local borrowing increased significantly, before to be slow down after 2011 with the implementation of a new approval process implying the Ministry of Interior.

In Thailand, the roles in solid waste management (MSW) and industrial waste management are organized by the Royal Thai Government, which is then divided among the central government, regional governments, and local governments. Each government is responsible for different tasks. The central government is responsible to stimulate regulation, policies, and standards. The regional governments are responsible for coordinating central and local governments. Local governments are responsible for waste management in their governed area.[6] Local governments themselves do not dispose of waste, but instead, hire private companies that have been granted that right by the PCD. A major problem is the lack of funding for waste management - the average Thai household pays less than one dollar a month to dispose of their solid waste (Suksamran, N. (2017). Poor waste management contributes to climate change and air pollution and directly affects many ecosystems and species. Landfills, considered the last resort in the waste hierarchy, release methane, a very powerful greenhouse gas linked to climate change. Methane is formed by microorganisms present in landfills from biodegradable waste, such as food, paper and garden waste (Dumrongkiat, 2016). After waste is collected, it is transported and treated. The transport process releases carbon dioxide - the most prevalent greenhouse gas — and air pollutants, including particulate matter, into the atmosphere.

Followed as reported from Wipataotin (2018) on the bid to cut plastic use irks shoppers, traders. This research on guidelines for solid waste management approaches at Kerng Sub-District Administrative Organization under the Maha Sarakham PAO, sample size group suggested that some parts of the waste might be incinerated or recycled. Energy from waste can be used to produce heat or electricity, which might then replace the energy, produced using coal or other fuels. Energy recovery of waste can thus help reduce greenhouse gas emissions. Recycling can help even more to lower greenhouse gas emissions and other emissions. When recycled materials replace new materials, fewer new materials need to be extracted or produced in the first place. As of the end of 2017, the 
Alternative Energy Development and Efficiency Department reported that there were 15 waste-to-energy plants operating - both biogas plants and waste incinerators - and generating a total 42.82 megawatts of electricity. Nine of these waste-to-energy plants in Bangkok, Phuket, Samut Prakan, Tak, Saraburi, and Khon Kaen are waste incinerators operated by private companies. Lack of waste segregation was another big problem that needed addressing to properly operate a waste-to-energy plant in Thailand, that 5,731 local administrative organizations have already grouped together with nearby counterparts to form 324 clusters for the efficiency enhancement of waste management (Visvanathan, 2014).

\subsection{Conflicts of Interest}

Thailand's waste management plan calls for 75 per cent of Thailand's total solid waste to be properly disposed of or recycled in some way by 2021, up from the current 49 per cent in 2021, the government and private sector plan to spend a total of 177 billion baht (US\$5.1 billion) on waste management technology and public awareness campaigns (Jiaranaikhajorn, 2014). According to the United Nations Ocean Conference Thailand produces about 50.000 tons of solid waste that finds its way into the sea each year, large quantities of coastal rubbish, especially in the upper reaches of the Gulf of Thailand impact sea life and coastal mangroves. Mangrove swamps are cluttered with garbage. At one site, the Bangkok Post reported that "Plastic bags, bottles, ropes, discarded noodle containers and even a rusty cooking appliance float in the water or are stuck in the mud under the green canopy (Bangkok Post News, 2016).

\subsection{Funding Statement}

Finally, this research study has discussed, most of guidelines for solid waste management approaches from the people's responses indicate that of the Waste Collection scale as to set at least twice a day and the public should be aware of the collection time and to develop for reducing the operating costs and the repeatability of the route to have a campaign for people to sort out biodegradable waste and carry out their own fermentation, which interpretation of the report by World Bank Group (2017), reported on Integrated solid waste management (ISWM) reflects the need to approach solid waste in a comprehensive manner with careful selection and sustained application of appropriate technology, working conditions, and establishment of a 'social license' between the community and designated waste management authorities (most commonly local government). ISWM is based on both a high degree of professionalism on behalf of solid waste managers; and on the appreciation of the critical role that the community, employees, and local (and increasingly global) ecosystems have ineffective SWM. ISWM should be driven by clear objectives and is based on the hierarchy of waste management: reduce, reuse, recycle - often adding a fourth ' $R$ ' for recovery. These waste diversion options are then followed by incineration and landfill, or other disposal options. This section should describe how readers may access the data underlying the findings of the study.

\section{Acknowledgments}

I would like to express my deepest appreciation to all those who provided me the possibility to complete this report. A special gratitude I give to our final year project manager, the Institute of Research and Development, Rajabhat Maha Sarakham University whose support the research scholarship and contribution in stimulating suggestions and encouragement helped me to coordinate my project especially in writing this report.

\section{References}

Bangkok Post News. (2016). Thailand State of Pollution Report 2015 (PDF). Bangkok Post. Pollution Control Department.

Council of State of Thailand. (2013). Sub-District councils and Sub-District administrative organizations act, be 2537 (1995) (in Thai).

Council of State of Thailand. (2014). Provincial Administrative Organizations Act, BE 2540 (1997) (in Thai).

Department of Local Organization. (2018). Kerng-Sub-District administration organization. Retrieved from http://www.kerng.go.th/

Department of Provincial Organization. (2018). Maha Sarakham provincial administrative organization. Retrieved fromhttp://www.pao-mk.go.th/index.php

Dumrongkiat, M. (2016). Media 'must help solve waste issue. Bangkok Post.

European Environment Agency. (2014). Waste: a problem or a resource? Retrieved 2 June 2014, from https://www.eea.europa.eu/signals/signals-2014/articles/waste-a-problem-or-a-resource

First Post News. (2016). How Thailand is hurtling towards a massive waste disposal crisis. First Post. 
Gheewala, S. (2011). Thai Style Recycling. Waste Management World (WMW).

Jiaranaikhajorn, T. (2014). Waste and Hazardous Substances Management Bureau. Pollution Control Department (PCD).

Organization of the government of Thailand. (2018). Provincial Administrative Organizations Act, BE 2540 (1997). National government organization act, BE 2534 (1991).

Ray, A. (2008). Waste management in developing Asia: Can trade and cooperation help?. The Journal of Environment \& Development, 17(1), 3-25.

Rujivanarom, P. (2018). Thailand becoming 'garbage bin of world'. The Nation News. Retrieved 11 June 2018, from http://www.nationmultimedia.com/detail/national/30347404

Suksamran, N. (2017). Suttipong told to clean up or else. Bangkok Post.

Techawongtham, W. (2016). Time to end our 'rubbish' behaviour. Bangkok Post.

The European Environment Agency. (2014). Directive 2008/98/EC of the European Parliament and of the Council of 19 November 2008 on waste and repealing certain Directives (Text with EEA relevance).

The U.S. Environmental Protection Agency. (2009). International waste activities. Retrieved from epa.gov

The United Nations Environment Programme. (2005). Solid waste management. Waste Quantities and Characteristics (pp. 31-38). Retrieved from unep.or.jp

The UNSD Glossary of Environment Statistics. (2013). Glossary of Environment Statistics. Wayback Machine.

Visvanathan, C. (2014). Hazardous and industrial solid waste management in Thailand-an Overview" (PDF). Asian Institute of Technology Thailand. Retrieved from www.faculty.ait.ac.th/visu/

Wilson, D. C., Velis, C., \& Cheeseman, C. (2006). Role of informal sector recycling in waste management in developing countries. Habitat International, 30, 797-808.

Wipataotin, A. (2018). Bid to cut plastic use irks shoppers, traders. Bangkok Post.

Wolsink, M. (1994). Entanglement of interests and motives: Assumptions behind the NIMBY-theory on Facility Siting. Urban Studies, 31(6), 851-866.

World Bank Group. (2017). Waste and environment. Retrieved from http://siteresources.worldbank.org/INTURBANDEVELOPMENT/Resources/336387-1334852610766/Cha p7.pdf

Yukako, O., \& Iwamoto, K. (2016). Waste is in the spotlight as governments think green. Nikkei Asian Review.

\section{Copyrights}

Copyright for this article is retained by the author(s), with first publication rights granted to the journal.

This is an open-access article distributed under the terms and conditions of the Creative Commons Attribution license (http://creativecommons.org/licenses/by/4.0/). 